Article

\title{
The Meaning of the Feminist T-Shirt: Social Media, Postmodern Aesthetics, and the Potential for Sociopolitical Change
}

\author{
Trine Kvidal-Røvik \\ Department of Tourism and Northern Studies, UiT-The Arctic University of Norway, 9509 Alta, Norway; \\ E-Mail: trine.kvidal@uit.no
}

Submitted: 30 November 2017 | Accepted: 28 May 2018 | Published: 29 June 2018

\begin{abstract}
This article examines the potential for political or social change as part of postmodern cultural expression in consumer culture. Throughout the article, I discuss the way sociopolitical messages, circulating in contemporary culture, represent an interesting element in terms of their intertextual referencing and postmodern blurring. Postmodern aesthetic features merge commodifying, resistive, and identifying processes, which can enable sociopolitical messages to spread into new arenas of resistance and fly under the radar, so to speak. In particular, I claim that new forms of engagement in social media communication produce an alternative venue for politics-one created by neoliberalism itself. I explain that sociopolitical messages presented via postmodern aesthetics in consumer culture, particularly when circulated using social media, can function counter-hegemonically, even while using hegemonic structures to gain commercial success. With this, the potential for change can come about; power lies in the hands (or social media accounts) of consumers.
\end{abstract}

\section{Keywords}

consumer culture, postmodern aesthetics, resistance, social media, sociopolitical change

\section{Issue}

This article is part of the issue "Media and Communication between the Local and the Global", edited by Jessica Gustafsson (Sodertorn University, Sweden) and Kinga Polynczuk-Alenius (University of Helsinki, Finland).

(C) 2018 by the author; licensee Cogitatio (Lisbon, Portugal). This article is licensed under a Creative Commons Attribution 4.0 International License (CC BY).

\section{Introduction}

As I travelled to Umeå, Sweden, my suitcase decided to make an extra layover stop in Stockholm. Scheduled to give a presentation the day after my arrival, I had to rush to the nearest shopping mall in search of something to wear. Somehow, I ended up at Gina Tricot, a Swedish fashion chain, where I found myself face-to-face with a white short-sleeved T-shirt decorated with the phrase "I only date feminists". As I have a long-standing fascination with sociopolitical messages in consumer culture, this T-shirt called out to me. Also, fresh in my mind was a fashion magazine I had just read. The first page of this magazine showed an image of a tall blond model wearing a T-shirt that stated "We should all be feminists", presented next to the questions "Can fashion ever be feminist? Or does it hurt feminism by its mere existence?" (Fardal, 2017, my tranlation). That evening in my hotel room overlooking Umeå, I did a quick Google search for "feminist T-shirt". The search yielded roughly 1,200,000 results! Among these results were images of an ASOS Feminist Floral Print T-shirt Dress and the interesting Boohoo Feminist T-shirt Dress (no pun intended). Some of the search hits also sent me into other circles of information, for instance, the story of Maria Grazia Chiuri (Dior's first female artistic director) partnering with artist Rihanna in designing the "We should all be feminists" T-shirt. I learned that the cost of the T-shirt was $\$ 710(!)$ and that Dior was giving a percentage of the proceeds from each sale to Rhianna's charity, Clara Lionel Foundation, which funds education, healthcare, and emergency response programs across the world. My search also provided information on how to purchase Chimamanda Ngozi Adichie's book We Should All Be Feminists (Adichie, 2014), the title of which inspired the $\$ 710$ Dior T-shirt, in addition to links to the author's TEDx talk of the same name, from which the personal essay in We Should All Be Feminists was adapted. I visited Adichie's 
Facebook page, and while doing so, I "met" several current and previous colleagues who at some point in time had "liked" the page. This slightly elaborate introduction, related to a fashion T-shirt decorated with a sociopolitical message, shows how a shirt's message can be intertwined in intertextual links and references-its message traveling through traditional and new media, via likes/dislikes and sharing, circulating in ways and with speeds that warrant attention from critics.

In this article, I engage with the issue of what it means, in terms of the possibility of sociopolitical change, when a product looks like a fashion item but presents a sociopolitical statement, which then circulates in consumer culture, lubricated by social media opportunities. Feminist T-shirt messages in the context of department stores, TEDx talks, books, magazines, social media, online shopping, and fashion runways, represent something interesting in terms of their intertextual referencing and postmodern blurring. Seeking to contribute to discussions of social activism and political change in the context of consumer culture, as put forth by critical scholars such as Duncombe (2002) and Mukherjee and BanetWeiser (2012), I argue that this form of message-and the cultural circulation of it-contains an important aspect of power. First of all, the fashion item to which the sociocultural message is attached renders potential resistance vague, ambiguous, and almost invisible, allowing it to reach places other forms of sociopolitical resistance may not be able to. Second, developments in social media make such cultural texts particularly interesting because with social media scholars describe how consumers and other stakeholders can become empowered by engaging in online communication (Bernoff \& Schadler, 2010; Gatzweiler, Blazevic, \& Piller, 2017; Jæger \& Kvidal-Røvik, 2015; Simon, 2011). According to Simon, "these new forms of engagement reveal an alternative venue for politics - one created by neoliberalism itself. As the state seems more remote, many consumers have shifted their political focus from the electoral arena to the market" (2011, p. 150). Even if few critics believe that the Internet can function as a remedy for social and political inequalities, communication continues to change with new developments in media, and consumers are "making themselves heard". Following this, Simon is calling for an increased focus on this situation-what he refers to as "contemporary politics" (Simon, 2011, p. 150).

In the following section, I put forth some traditional critical perspectives on consumer culture before presenting relevant perspectives from cultural theorists who have looked at the ideas of agency and power in consumer culture. Next, I discuss postmodern aesthetics and the accompanying possibility of change, which hinges on a particular media-experienced consumer, before I address how developments within media culture-specifically social media-which play an important role in bringing about change, can function counter-hegemonically in consumer culture, even while using hegemonic structures to gain commercial success. The reflections I present in this article are anchored in interpretive perspectives. More specifically, they are embedded approaches as developed within critical rhetoric (Endres, Hess, Senda-Cook, \& Middleton, 2016; Middleton, Hess, Endres, \& Senda-Cook, 2015). This means that I make use of my own experiences and interactions with cultural texts as entry points for discussions on broader issues of sociopolitical change and consumer culture. The article speaks to an interest in the potential for political or social change as part of postmodern cultural expression in consumer culture, yet it also brings in another especially interesting dimension, namely, developments in media-specifically social media-and what these developments might mean in terms of the possibility of social and political change.

\section{Critical Cultural Perspectives on Consumption and Change}

In 2013, H\&M ran its "WaterAid" campaign, of which Helena Helmersson, H\&M's Head of Corporate Social Responsibility, said: "WaterAid operates in countries where H\&M suppliers are located. We feel that it is very important for us to contribute to better livelihoods for people in these regions. We are very proud of being part of making a difference" (Radovic, 2012, para. 3). Strolling through H\&M during the time of this campaign, I remember reflecting on the meaning of this statement, thinking that it felt too simplistic and a bit shallow to buy a sparkly bikini and feel like I had made a difference in the world. Could I honestly wear the bikini to a pool party, sit on a green lawn in the middle of what was only a sprinkler system away from a desert (I was in Utah at the time), and tell myself I had made a positive contribution via my purchase? Traditional cultural critics of the Frankfurt School would say "no"; they paint a pessimistic picture of the consumer and modern society, in which market society is seen as an arena of manipulation and enslavement. The consumer is depicted as "a mindless, passive creature, systematically pacified by capital-holders through their propaganda mediums, namely, the culture industries and ideology of consumerism" (Izberk-Bilgin, 2010, pp. 302-303). Leading Frankfurt School theorist, Adorno explains how individuals, unconsciously submissive to a capitalist system, are what guarantees the system's continued existence (Adorno \& Horkheimer, 1972). Media reinforce a dynamic in which people are exploited while under the false impression of having "freedom" and "choice". Being part of a consumer culture and critiquing this social order is unthinkable as the power dynamics of market society and the consumerist ideology hinder all sources of resistance. The consumer is trapped in a dominating and manipulative system, and resistance can neither materialize from outside nor within this system. Needless to say, Adorno and his likes would not be impressed by an H\&M WaterAid bikini.

Following from this perspective, little room exists for social or political change in the wake of a Dior T-shirt on 
the runway, even if the printed message on the front of it appears to be a protest against a hegemonic masculinity. In fact, rather the opposite is true; the shirt can be seen as pulling consumers' attention away from "real" political and social issues. Also, the WaterAid bikini and feminist T-shirts could actually be said to undermine the very causes they speak out in support of. Shugart, Waggoner, and Hallstein (2001) explain how messages of resistance can be coopted and commodified. They argue that what seems to be resistant text may turn out to actually perpetuate the very thing it gives the impression of challenging. Similarly, Ponte and Richey (2014) warn against the potential for change with these types of artifacts. Echoing Hickel (2012), they say that:

Consumerist activism, development discourse, and pink-ribbon feminism all partake of the liberal fallacy that good will and cooperation and compromise will suffice to fix the intractable problems of poverty and inequality-problems that are imagined to be static and given, as if outside the realm of history and politics. (Ponte \& Richey, 2014, p. 83)

In light of these sentiments, the possibility for agency and resistance and the potential for political or social change as part of any commercial cultural expression are hard to see unless, that is, people step outside of the marketplace (Izberk-Bilgin, 2010). Simon (2011) is concerned that the act of buying can become a substitute for politics and that "while buying can make a difference in the distribution of power and buyers can force companies to change how they operate in order to hold onto their market shares, this form of civic engagement can also make dissent fade away" (p. 162). Simon is in line with previous critical scholars who have been concerned that choices related to consumption can mask real political engagement. He is worried that this obscures problematic issues, making real solutions harder to see and taking away an important sense of urgency. He asks:

Why enlist in a political crusade or a long-term political project if you are already doing something to help the environment or the less fortunate each and every day, like buying a venti skim milk latte from a company that says it makes things better? (Simon, 2011, p. 162)

In other words, one fear would be that someone, through their purchase of a feminist T-shirt or WaterAid bikini, decides "this is it", in terms of political activism on their part and, thus, the consumer's act serves to sidetrack or undermine "real" political acts that might otherwise have taken place.

\section{Complicating the Understanding of Consumption}

In 2007, Gap introduced its “RED” marketing campaign and the RED organization as a for-benefit brand designed to help eliminate AIDS in Africa. Ten years later, Gap says that the RED campaign has revolutionized the way that non-profits generate donations: "Consumers want to show which causes they're supporting. A fashionable product that backs up a worthy cause with a majority of their profits was an innovative way to get people involved, and one that continues to march on" (GAP, 2017). Sociopolitical awareness combined with consumption, as exemplified by the RED campaign, has been discussed extensively by theorists, often by those with an interest in modes of resistance that include acts of consumption. Several cultural theorists underscore that resistance is closely interwoven with broader issues of social order, agency, and power (Banet-Weiser, 2012; Banet-Weiser \& Lapsansky, 2008; Condit, 1989, 1994; De Certeau, 1984; Hebdige, 1988; Jhally, 1990; Skretting, 2004; Sturken \& Cartwright, 2001). While still linked with criticism put forth by scholars associated with the Frankfurt School, these perspectives provide a more open approach to dynamics of power and influence in consumer culture. In particular, cultural sociologist De Certeau (1984) provides a sophisticated account of consumption as a potential site of resistance when he theorizes consumers as creative and playful agents, devising innovative tactics that counteract strategic maneuvers of powerful corporate players. He talks about how "users make (bricolent) innumerable and infinitesimal transformations of and within the dominant cultural economy in order to adapt it to their own interests and their own rules" (De Certeau, 1984 , p. xiv). Thus, consumption is never a passive enterprise; rather, it is another form of production because it involves the consumers' art of using and making-do. According to De Certeau (1984), consumers are "poachers" who negotiate, reinterpret, and appropriate dominant meanings. This celebratory approach offers an alternative theoretical lens, whereby consumer empowerment manifests through "the creative adaptations and manipulations of the marketer-intended meanings and uses of products and advertisings" (Denegri-Knott, Zwick, \& Schroeder, 2006, p. 959). The active involvement of consumers in the process of consumption has also been explored in consumer research, where scholars have put forth interesting discussions about issues like anticonsumption and consumer resistance (Cherrier, Black, \& Lee, 2011; Izberk-Bilgin, 2010; Kates \& Belk, 2001; Kozinets, Handelman, \& Lee, 2010; Varman \& Belk, 2009), purchasing power (Denegri-Knott et al., 2006), and brand management as a process that incorporates an understanding of consumers' active agency (Arvidsson, 2005; Holt, 2002) and the possibility of responsive corporate decision-making within a neoliberal context.

Consumer researchers and sociologists of consumption have also been interested in how consumers resist the disciplining power of the market (Denegri-Knott, 2004; Fiske, 1989, 1993; Kozinets \& Handelman, 2004). Fiske (1989) argues that popular culture is a site of power relations and that it always bears traces of the constant struggle between power and various forms of resistance to or evasions of it. In line with critical theoret- 
ical perspectives, Fiske (1993) acknowledges that viewpoints represented in commercial culture are narrow; however, he says that the commercial culture's reasons for exclusion are generally consistent with its accepted function of making a profit. He makes an especially important and related point when he says that this exclusion is superior to more transparent exclusions from the public sphere, which homogenize and organize cultural representations around the interests of the power bloc. Drawing on Fiske's argument, commercial texts potentially provide more room for resistance than more "obvious" public outlets for resistive ideologies. Thus, a T-shirt presented on the runway or an image in a fashion magazine slips under the radar, so to speak, and can move around in arenas where the explicit questioning of social and political issues is usually rare.

\section{Postmodern Aesthetics}

In 1985, United Colors of Benetton was one of the first companies to challenge the traditional advertising formula when it started referencing issues related to world peace and harmony in its advertising campaigns. The company soon moved on to using more controversial images connected to political and social issues in its ads, arguably inspiring significant changes within the advertising industry (Vézina \& Paul, 1997). The company was widely criticized for commodifying social and political issues (Schroeder, 2002; Seppänen, 2001), and the claim can also be made that no other company has managed (or wanted) to create as shocking and provoking images concerning social and political issues as they did. It was the jarring encounter with the United Colors of Benetton ads that first made me interested in postmodern aesthetics and sociopolitical messages in consumer culture.

The word "postmodernism" is, as Docherty (1993) notes, characterized by an ambiguity in that it can refer to an aesthetic style but also a political and cultural reality. Lyotard (1993) provides a pivotal account of postmodernity based on the collapse of "grand narratives" (such as Marxism) and their replacement with "little narratives" in the "wake of technologies which have transformed our notion of what constitutes knowledge" (Edgar \& Sedgwick, 1999, p. 295, emphasis in original). Jameson (1992) conversely argues that what is known as "postmodernism" is best understood as the cultural logic of late capitalism. Edgar and Sedgwick (1999) suggest that the only thing certain about postmodernism is that "the uses of the word display such a diversity of meanings, that it defies simple definition" (p. 295). Presenting a thorough discussion of postmodernism is beyond the scope of this article; however, I can note that I keep in mind some aspects of the theorists referenced above when I-loosely based on the work of Harms and Dickens (1996) - understand postmodernism as a theoretical/analytical framework critical of totalizing theories, which is based in poststructuralist and deconstructionist approaches (in which knowledge is seen as discursive and subjectivities as fluid). Postmodern styles and aesthetics, however, are at the core of this article and, as such, demand a little more explanation.

In short, postmodern styles and aesthetics include fragmentation, a referencing of other cultural texts, and a blurring of the lines between art and commercialized texts (Hebdige, 1988; Hitchon \& Jura, 1997; Moore, 2004). Two of these elements are particularly relevant to this article. First, a central aspect of a postmodern aesthetic is blurring. Fact, fiction, art, commercialismpostmodern aesthetics complicates genre norms and expectancies, appealing to an audience thoroughly steeped in the world of consumption (Sturken \& Cartwright, 2001). United Colors of Benetton's sociopolitical advertising campaigns of the 1980s and 1990s provided numerous examples of such postmodern blurring. Many different, sometimes conflicting, meanings could be taken from the images used by the company in their campaigns as they "played" with different discursive genres. For instance, in 1989, United Colors of Benetton published an ad that portrayed a black woman nursing a white infant-an image that received responses both in the form of prizes as well as censorship. The breastfeeding ad included visual aspects from traditional advertising, with its crisp colors and slim, spotless "beheaded" female body, but the controversial issue of race (via a black woman nursing a white child), as well as the visual and conceptual contrasts in the ad, were aspects that seemed to align with contemporary art photography. A few years later, United Colors of Benetton began using documentary photographs and genuine images of catastrophes in its advertising. For example, in the spring of 1992, the company launched a campaign organized around what it called "The shock of reality". The seven ads in this campaign were images produced by photo journalists and had already been published in newspapers and magazines, so the postmodern blurring of genres was obvious in this instance. One of the pictures from this campaign - an image of the terminally ill, gay, AIDS activist David Kirby-is one of the few ads still included on United Colors of Benetton's webpage today, where it is described as one of the most important images in the company's many "social campaigns" (Benetton, 2017).

Not long after this ad was released, similar examples of postmodern blurring were used by other brands in their ads. One of these companies was Kenneth Cole. I remember flipping through the pages of a Kenneth Cole brochure before Christmas in 2003 and finding several interesting, and at times troubling, pieces of information about society, which were presented as part of the company's advertising. The information was related to issues like crime, HIV, and plastic surgery. But Kenneth Cole also provided interesting examples of intertextuality, which is the second aspect of a postmodern aesthetic that I want to emphasize.

A specific way intertextuality is expressed is via pastiche, which involves the "imitation or, better still, the mimicry of other styles" (Jameson, 1998, p. 130). This is 
the ad that dresses up as art or art that dresses up as an ad; it is the sociopolitical message in ad form or an ad using sociopolitical messages to sell a product. Discussing similar dynamics, some scholars use concepts like double- (or triple- or multiple-) coding to emphasize how postmodern discourse works to "create meaning out of the dialectic generated by juxtaposition and the resulting cognitive tension" (Gude, 1999, p. 22). Pastiche does not stand outside of what it comments on; it does not point fingers and tell jokes but, rather, is a "blank parody, [a] parody that has lost its sense of humor" (Jameson, 1998, p. 131). When the Kenneth Cole ads used pastiche, they brought together fragments from other textual styles into a new textual form. Specifically, Kenneth Cole's pastiche consisted of aspects from sociopolitical messages that encouraged an awareness of HIV and identity theft, in combination with aspects of traditional ads-beautiful, skinny people in stylish clothing.

United Colors of Benetton also produced examples of intertextuality. For instance, a remarkable similarity exists between the ad image of David Kirby and traditional, Western images of Jesus Christ. The ad image as a whole-David Kirby is in bed surrounded by his familyhas, in many ways, a strong resemblance to Michelangelo's famous marble statue entitled Pietà, which depicts the Madonna holding Christ's (dying) body in her arms. Even if it is unlikely that the image of Kirby was staged with the intention of imitating Michelangelo's Pietà, this resemblance and intertextual link is relevant. This link may have played into why this image was originally chosen for publication in the British newspaper, and it may certainly have played into why United Colors of Benetton's art director, Oliviero Toscani, decided to include this image in the company's advertising campaign at the time. While the company never explicitly suggested Kirby's figure should be seen as a reference to Jesus Christ, the ad nevertheless supports these connotations via its intertextual aesthetic. The Christ-like image, combined with contextual knowledge about Kirby, his homosexuality, and his unspeakable disease (at that time), created strong cultural tension.

As part of a postmodern aesthetic, mediated simulations come to seem more "real" than the things they are attempting to portray (Harms \& Dickens, 1996; Shugart et al., 2001). Related to this, Baudrillard (1983) introduces the concepts of "hyperreality" and "simulation," which describe a realm in which distinctions between media and reality get destroyed. These terms also refer to the unreal nature that is created by a contemporary culture of mass communication dominated by spectacles and simulations. Reality, thus, is replaced by a more-realthan-real substitute. A postmodern style or aesthetic acknowledges consumers' media awareness by employing intertextuality and playing with fragmentation and genre blurring. Cultural texts' engagement with increasingly sophisticated media and a visually literate audience can be understood as part of a postmodern condition in which audiences do not find reality in itself satisfactory unless it is recast as fascinating narratives in media. According to critical theorists, this need to view reality through the lens of intriguing narration causes a blurring of fact and fiction and a loss of depth, context, and historical sense (Jameson, 1998) - a postmodern loss of reality and history replaced by commodities and commercial texts, which consumers use to create imaginary narratives (Appadurai, 1996).

Debord (1994) explains that, as part of capitalism's consequences of commodification and alienation, everything that once directly lived becomes transformed into representations. This "society of the spectacle" is dominated by consumerist patterns and a monopoly of massproduced images, which undermine possibilities for critical dialogue. In other words, spectacles that are consumed are strategically created to serve the interests of those in power, and images become the final form of commodity reification. Importantly, Baudrillard (1983) claims that, since we have nothing real anymore, ideological criticism, which seeks to restore and make visible the illusory nature of capitalist freedom -in line with the Frankfurt School-deals with a false problem. The issue is not that media mask oppression and unjust social relations by presenting a false reality, as Frankfurt School critics (and also Debord) would like to argue, but instead that a media-created hyperreality conceals that nothing real exists. Postmodern aesthetics invites reading on the surface. Focusing on the surface becomes a way of avoiding the chaos that seems embedded in ambiguous postmodern messages the ads appear to attempt to communicate. From a critical cultural point of view, commodity texts present something consumers desire in one instance and something they fear in the next. This balance, but also tension, indicates that postmodern aesthetics potentially embody a double-siddedness in terms of fueling and helping to resist the status quo. So, although such texts traditionally present a fantasy of what consumers' lives could be like, as part of dominant culture, the texts are also subject to counter-hegemonic forces (Sturken \& Cartwright, 2001). Following this, they can function as a form of resistance "restrained and shaped by the machinery from which it emerges" (Harold, 2004, p. 197).

The employment of aesthetic features, such as fragmentation, intertextuality, and blurring, opens up the potential for interpretations that miss or even counter the hegemonic ideal of consumer dynamics. Specifically, due to postmodernist conditions/aesthetics in which fragmentation, and perhaps confusion, is emphasized, power is not automatically a direct, one-way issue. In fact, Harms and Dickens (1996) say this postmodern fragmentation compromises control. This understanding of a postmodern aesthetic supports a view of postmodern consumer culture as a dynamic process of consumption in which commodities may embody both hegemonic and counter-hegemonic meanings. Furthermore, McKenzie (2002) points out that cultural resistance can be performed through parodic appropriations, whereas Ott and Herman (2003) argue that postmodern images can 
have resistive functions when they play into "symbolic and material practices that challenge, subvert, or suspend" established cultural codes, rules, or norms (p. 251). On a related note, Harold (2004) emphasizes that postmodern cultural texts can function as resistive rhetorical tools from the "inside" of whatever they seek to comment on, specifically through the "rhetorical process of intervention and invention" of culture jamming (p. 192). This picks up Fiske's (1993) point on how commercial texts can create valuable room for resistance in consumer culture. Finally, DeLuca (1999) points to the resistive potential in the use of jarring "image events" to attract media attention and interrupt the comfortable equilibrium of the status quo.

The feature of fragmentation and the multiple, conflicting interpretations connected with a postmodern aesthetic undermine a simple, hegemonic function of such commodities in that they challenge established cultural codes, rules, or norms. These elements offer the resource to create a consumer identity connected with something else-giving people a way to express their sociopolitical awareness via the consumption of a certain product. Consumers are offered a commercialized way of expressing their political identities by aligning themselves with a certain image or by employing symbolism in such a way as to create an image of sociopolitical awareness. As critics, then, says McRobbie (1994), we need to pay attention to "how the tinsel and the glitter can produce meaning, in a different but no less significant kind of way than the great deep works of modernism" (p. 4). In her view, postmodern conditions such as fragmentation and incompleteness "need not mean loss of political capacity" (p. 50) but can point to new forms of struggle and critical work. By paying closer attention to the social practices of consumer culture, critics are able to gain a better understanding of the significance of popular culture.

So, what does this indicate? What, then, is the meaning of Dior's "We should all be feminists" T-shirt or the more affordable "I only date feminists" alternative from Gina Tricot? And how, if at all possible, could such commodified messages come to function as a form of resistance? My point is that they do not inherently possess resistance in their style and aesthetics, nor does the consumers' act of purchasing equate to resistance. However, along with the postmodern aesthetic that these items represent and the consumer culture they are a part of, a potential for sociopolitical resistance does exist. This might become activated when consumers use the feminist T-shirt as a rhetorical resource. And with social media, the "use" of such rhetorical resources might spread further and at higher speeds than before. This will be explained next.

\section{New Media-New Opportunities?}

Since its rise in the early 1990s, the world's networked population has grown from the low millions to the low billions (Shirky, 2011, p. 28). And while the Internet is not equally available to everyone, it is used by a growing number of people every day. These individuals make up the engine in a new media world, and their network of friends and acquaintances make up the social dimension of social media (Berthon, Pitt, Plangger, \& Shapiro, 2012). With this, the communication landscape becomes denser, increasingly complex, and more participatory. New developments in media, specifically social media, have prompted discussions of consumers' power to influence social orders via the opportunity to engage in online communication (i.e.Bernoff \& Schadler, 2010; Fuchs, 2017; Gatzweiler et al., 2017; Gerbaudo, 2012; Labrecque, vor dem Esche, Mathwick, Novak, \& Hofacker, 2013; Loader \& Mercea, 2011; Mattoni \& Treré, 2014; Morozov, 2011; Shirky, 2011; Simon, 2011; Valenzuela, Arriagada, \& Scherman, 2014; Valenzuela, Correa, \& Gil de Zúñiga, 2018).

Many critics are skeptical of the positive effects of social media. For instance, in a book strikingly entitled The Net Delusion: How Not to Liberate the World, Morozov (2011) refers to feel-good online activism as "slacktivism", which holds zero political or social impact. In an overview of research on social media's role in political campaigns and elections, Towner (2017) shows that citizens do not employ social media to become more politically knowledgeable. In the recent book Social Media: A Critical Introduction (2017), which provides an in-depth and thorough account of power relations as part of the digital media landscape, Fuchs says that when it comes to assessing whether social media advance or harm the political public, he leans toward the former of these positions (p. 231). Fuchs (2017) connects his skepticism to the fact that capitalism constrains social media, and he points out that social media activity must not be mistaken for more profound forms of protest.

Other scholars express a more optimistic vision of the influence of social media. Discussing blogs, Rettberg (2014) speaks about how some such social media platforms reach far more daily readers in certain segments of the population than most newspapers. Shirky (2011) claims "the networked population is gaining greater access to information, more opportunities to engage in public speech, and an enhanced ability to undertake collective action" (Shirky, 2011, p. 29). Shirky also indicates that social media are powerful because they allow "people to privately and publicly articulate and debate a welter of conflicting views" (Shirky, 2011, p. 34). In line with this idea, Dean (2005) even goes so far as to talk about communicative capitalism that enables statements and singular acts of resistance-which in and of themselves may not be political-to be "articulated together with other struggles, resistances and ideals in the course or context of opposition" (p. 57). Similarly, Labrecque et al. (2013) say that the social media landscape has allowed consumers not only to create content themselves but also to amplify their voices across the globe. As Rettberg (2014) says, today you "don't need to own a printing press, a newspaper or a television station to share your 
ideas with the world. Anyone with Internet access can publish whatever they want" (p. 19). Towner (2017) further explains that social media sites are important hubs of political information and activity, which have "transformed citizen-to-citizen and citizen-to-government interaction in a manner not seen before" (p. 167). With this increased access, what we as users do and how we use media changes, and access to information becomes far less important, politically, than access to conversation (Shirky, 2011). Thus, social media allow for a new kind of participation (Jenkins \& Carpentier, 2013).

An active audience, of course, does not guarantee a critical one, and cultural scholars underscore that active media use does not mean that people have much direction with regard to usage (Harms \& Dickens, 1996). Mattoni (2016) is correct in pointing out that a celebration of the emancipatory power of communication technologies is of little use in terms of understanding the use of these media. In different ways, other scholars put forth similar arguments when they call for a more nuanced approach to the complexities across different social media platforms (Valenzuela et al., 2018) as well as approaches to social media that take into account specific cultural contexts and embedded uses (Gerbaudo, 2012). Towner's (2017) overview of research on social media and political campaigns brings out some of this complexity; even though the overview points out that social media use does not enhance political knowledge, social media use is shown to increase digital engagement and also to increase offline political participation, such as voting and signing a written petition (p. 169). Tufekci (2013) suggests that instead of seeing social media platforms as encouraging "slacktivism", we should examine the ways in which these media mechanisms can allow for public attention to certain causes or campaigns.

I align myself with such understandings, where I view social media as relevant and potentially important when it comes to the capacity for influence, albeit without a guarantee for what it will do. Simon (2011) provides an interesting argument for how sociopolitical resistance could come to really matter in the context of social media. He explains that, first, consumers would have to recognize the connection between the things they purchase and the related worlds of production, labor, and exchange, and second, they must see that their purchases matter in terms of people, places, and power. Then, says Simon (2011), the third step in this process would be for consumers to move from politicization to politics. He explains that in order for this to happen, consumers must talk out loud about their understanding of the connectivity of an object to other processes:

They must say to friends on the phone or on Facebook or over email that they are buying or not buying something for a specific set of reasons....This way they make clear in their own words the larger meaning and intentions of their consumer actions. They will own them, therefore, apart from the actions of socially responsi- ble corporations that sometimes sponsor (and co-opt) political buying. (Simon, 2011, p. 163)

Referring to Lawrence Goodwyn (1978), Simon (2011) explains that this last step is the development from consciousness-raising to expression of an autonomous, political sort. Simon suggests that social media is a very important aspect of (potential) change, not because of what social media do but because of what they allow consumers to do, or how they allow consumers to spread the words about what they do and why they do what they do. The Internet, thus, is an important medium because it offers alternative channels to disseminate counter-hegemonic content and prompt instant mobilization (Aouragh, 2016). This underscores that the feminist T-shirt in itself is less interesting, but the postmodern style it represents, combined with the cultural context in which it circulates, is key.

In light of this, sociopolitical messages placed on fashion T-shirts, circulating in the context of social media, can become a rhetorical resource for resistive communication. With a postmodern aesthetic and in light of social media developments, which open up the possibility of playing out political positions in new ways, a potential for disruptive moments and actions arises. Understanding this calls for critics who are interested in sociopolitical resistance in contemporary culture to look beyond what is printed on the front of a fashion T-shirt and think about how it circulates in consumer culture. With this in mind, I am arguing for a potential of disruptive moments and actions in the sporting of a feminist T-shirt because of how this "utterance via attire" may spread via social media.

\section{Conclusions}

I did not purchase that feminist T-shirt in Umeå, Sweden, but maybe I should have as the presentation I was to deliver the following morning dealt with gendered representations from a critical feminist perspective. What stopped me was, perhaps, the fear that my peers would think of my attire as silly, naïve, or trivial, even though, ironically enough, I am interested in the potential for social or political change as part of postmodern cultural expression. Or, to borrow a phrase from McRobbie (1994), I am thinking seriously about the trivial. A feminist T-shirt, presented in a Gina Tricot store, can certainly be seen as "passing" for just another fashion idea. But that does not mean that it cannot also be something else-something more. Had I put my money where my mouth is by wearing such a T-shirt, I could have undertaken another means of addressing the issue of gender inequality. Postmodern aesthetic features enable a merging of commodifying, resistive, and identifying processes; this can allow sociopolitical messages to move into new arenas and fly under the radar, so to speak. They are powerful in that they cannot be controlled and in that they can show up in unexpected places. 
All-in-all, resistance that is intertwined with consumption is important to understand because it can reach places where "ordinary" political resistance is prevented from visibility. This is a type of resistance that slides in between the cracks and can potentially carve out a space for deeper, more profound challenges to problems in society. This resistance is also important because, due to the vehicle of consumption rather than the structures of "traditional" political resistance, it can reach groups that are not interested in joining a political party or signing up for a lasting membership in a certain organization that fights for a specific cause. Resistance via consumption, when not marked as "resistance", is also something that can appear less binding. Wearing a T-shirt with the message "I only date feminists" does not require you to "be" a feminist in the same way as signing up as a member of a radical feminist group does, but this does not mean that wearing it cannot be a rhetorical resource for making a contribution toward sociopolitical change in society.

Anthropologist James C. Scott (1985) writes interestingly about "everyday forms of resistance", which can work together in "petty acts of insubordination" carried out by the weak (p. 91). Along with changes in the ways people use media (specifically social media), individuals' engagement with society changes. People's "likes" (and also "dislikes") matter. Following this, commodity culture can be used to resist dominant hegemony while simultaneously taking advantage of hegemonic structures to gain commercial success. In fact, commodity culture can contain "politics that do not look like politics", to borrow a section title from Stephen Duncombe's book Cultural Resistance Reader (2002). An opportunity exists for us, as consumers, to make use of devising tactics in order to speak out against something, especially as such protests can be lubricated and reinforced via social media. We can spread information faster and over larger distances. With this, a potential opening for change exists; power lies in the hands, on the T-shirts, and in the social media accounts of consumers.

\section{Acknowledgements}

I am very grateful to the editors and peer reviewers, who provided valuable comments and suggestions for this final draft.

\section{Conflict of Interests}

The author declares no conflict of interests.

\section{References}

Adichie, C. N. (2014). We should all be feminists. New York, NY: Anchor Books.

Adorno, T. W., \& Horkheimer, M. (1972). Dialectices of enlightenment. New York: The Seabury Press.

Aouragh, M. (2016). Social media, mediation and the
Arab revolutions. In C. Fuchs \& V. Mosco (Eds.), Marx in the age of digital capitalism (pp. 482-515). Leiden, Boston: Brill.

Appadurai, A. (1996). Modernity at large: Cultural dimensions of globalization (Vol. 1). Minneapolis, MN: University of Minnesota Press.

Arvidsson, A. (2005). Brands: A critical perspective. Journal of Consumer Culture, 5(2), 235-258.

Banet-Weiser, S. (2012). AuthenticTM: The politics of ambivalence in a brand culture. New York, London: NYU Press.

Banet-Weiser, S., \& Lapsansky, C. (2008). RED is the new black: Brand culture, consumer citizenship and political possibility. International Journal of Communication, 21(2), 1248-1268.

Baudrillard, J. (1983). Simulations. New York, NY: Semiotext(e).

Benetton Group. (2017). Social commitment. Retrieved from https://no.benetton.com/identity/social-com mitment/

Bernoff, J., \& Schadler, T. (2010). Empowered. Unleash your employees, energize your customers, transform your business. Boston: Harward Business School Press.

Berthon, P. R., Pitt, L. F., Plangger, K., \& Shapiro, D. (2012). Marketing meets Web 2.0, social media, and creative consumers: Implications for international marketing strategy. Business horizons, 55(3), 261-271.

Cherrier, H., Black, I. R., \& Lee, M. (2011). Intentional nonconsumption for sustainability: Consumer resistance and/or anti-consumption? European Journal of Marketing, 45(11/12), 1757-1767.

Condit, C. M. (1989). The rhetorical limits of polysemy. Critical Studies in Media Communication, 6(2), 103-122.

Condit, C. M. (1994). Decoding abortion rhetoric: Communicating social change. Urbana, Chicago: University of Illinois Press.

Debord, G. (1994). The society of the spectacle. New York, NY: Zone.

De Certeau, M. (1984). The practice of everyday life (S. Rendell, Trans.). Berkeley: University of California Press.

Dean, J. (2005). Communicative capitalism: Circulation and the foreclosure of politics. Cultural Politics, 1(1), 51-74.

DeLuca, K. M. (1999). Image politics. New York, NY: Guildford Press.

Denegri-Knott, J., Zwick, D., \& Schroeder, J. E. (2006). Mapping consumer power: An integrative framework for marketing and consumer research. European Journal of Marketing, 40(9/10), 950-971.

Denegri-Knott, J. (2004). Sinking the online "music pirates:" Foucault, power and deviance on the web. Journal of Computer-Mediated Communication, 9(4), 00-00.

Docherty, T. (1993). Introduction. In T. Docherty (Ed.), 
Postmodernism. A reader (pp. 1-33). New York, London: Harvester Wheatsheaf.

Duncombe, S. (2002). Cultural resistance reader. London, New York: Verso.

Edgar, A., \& Sedgwick, P. (1999). Key concepts in cultural theory. London, New York: Routledge.

Endres, D., Hess, A., Senda-Cook, S., \& Middleton, M. K. (2016). In situ rhetoric: Intersections between qualitative inquiry, fieldwork, and rhetoric. Cultural Studies? Critical Methodologies, 16(6), 511-524.

Fardal, S. (2017, March). Velkommen [Welcome]. Elle Norge, p. 31.

Fiske, J. (1989). Reading popular culture. London: Hyman.

Fiske, J. (1993). Power plays, power works. London: Verso.

Fuchs, C. (2017). Social media: A critical introduction (2nd ed.). Los Angeles, London, New Delhi: Sage.

GAP. (2017). Gap's 10-year (RED) anniversary: How a shirt can change the world. Gap Inc. Retrieved from https://adressed.gapinc.com/blog/2016/7/26/gaps10-year-red-anniversary-how-a-shirt-can-change-the -world

Gatzweiler, A., Blazevic, V., \& Piller, F. T. (2017). Dark side or bright light: Destructive and constructive deviant content in consumer ideation contests. Journal of Product Innovation Management, 34(6), 772-789.

Gerbaudo, P. (2012). Tweets and the streets: Social media and contemporary activism. London: Pluto Press.

Goodwyn, L. (1978). The populist moment: A short history of the agrarian revolt in America. New York, NY: Oxford University Press.

Gude, O. (1999). Color coding. Art Journal, 58(1), 21-26.

Harms, J. B., \& Dickens, D. R. (1996). Postmodern media studies: Analysis or symptom? Critical Studies in Media Communication, 13(3), 210-227.

Harold, C. (2004). Pranking rhetoric:"Culture jamming" as media activism. Critical Studies in Media Communication, 21(3), 189-211.

Hebdige, D. (1988). Hiding in the light: On images and things. London, New York: Routledge.

Hickel, J. (2012). Liberalism and the politics of Occupy Wall Street. Anthropology of this Century [online], 2012(4), Retrieved from: http://aotcpress. com/articles/liberalism-politics-occupy-wall-street/

Hitchon, J. C., \& Jura, J. O. (1997). Allegorically speaking: Intertextuality of the postmodern culture and its impact on print and television advertising. Communication Studies, 48(2), 142-158.

Holt, D. B. (2002). Why do brands cause trouble? A dialectical theory of consumer culture and branding. Journal of Consumer Research, 29(1), 70-90.

Izberk-Bilgin, E. (2010). An interdisciplinary review of resistance to consumption, some marketing interpretations, and future research suggestions. Consumption, Markets and Culture, 13(3), 299-323.

Jæger, K., \& Kvidal-Røvik, T. (2015). “Du får som fortjent": Destinasjonsmarkedsføring, eventer og sosiale medier ["You will get what you deserve": Destination marketing, events, and social media]. In K. A. Ellingsen \& T. Blindheim (Eds.), Regional merkevarebygging [Regional branding] (pp. 135-150). Oslo: Fagbokforlaget.

Jameson, F. (1992). Signatures of the visible. London: Routledge.

Jameson, F. (1998). Postmodernism and consumer society. In H. Foster (Ed.), The anti-Aesthetic: Essays on postmodern culture (pp. 127-144). New York, NY: The New Press.

Jenkins, H., \& Carpentier, N. (2013). Theorizing participatory intensities: A conversation about participation and politics. Convergence, 19(3), 265-286.

Jhally, S. (1990). The codes of advertising: Fetishism and the political economy of meaning in advertising. London: Routledge.

Kates, S. M., \& Belk, R. W. (2001). The meanings of lesbian and gay pride day resistance through consumption and resistance to consumption. Journal of Contemporary Ethnography, 30(4), 392-429.

Kozinets, R. V., \& Handelman, J. M. (2004). Adversaries of consumption: Consumer movements, activism, and ideology. Journal of Consumer Research, 31(3), 691-704.

Kozinets, R. V., Handelman, J. M., \& Lee, M. S. W. (2010). Don't read this; or, who cares what the hell anti-consumption is, anyways? Consumption Markets \& Culture, 13(3), 225-233.

Labrecque, L. I., vor dem Esche, J., Mathwick, C., Novak, T. P., \& Hofacker, C. F. (2013). Consumer power: Evolution in the digital age. Journal of Interactive Marketing, 27(4), 257-269.

Loader, B. D., \& Mercea, D. (2011). Networking democracy? Social media innovations and participatory politics. Information, Communication \& Society, 14(6), 757-769.

Lyotard, J.-F. (1993). Answering the question: What is postmodernism? In T. Docherty (Ed.), Postmodernism. A reader (pp. 38-46). New York, London: Harvester Wheatsheaf.

Mattoni, A. (2016). Media practices and protest politics: How precarious workers mobilise. London: Routledge.

Mattoni, A., \& Treré, E. (2014). Media practices, mediation processes, and mediatization in the study of social movements. Communication Theory, 24(3), 252-271.

McKenzie, J. (2002). Perform or else: From discipline to performance. London, New York: Routledge.

McRobbie, A. (1994). Postermodernism and popular culture. New York, NY: Routledge.

Middleton, M., Hess, A., Endres, D., \& Senda-Cook, S. (2015). Participatory critical rhetoric. Theoretical and methodological foundations for studying rhetoric in situ. London, New York: Lexington.

Moore, R. (2004). Postmodernism and punk subculture: Cultures of authenticity and deconstruction. The 
Communication Review, 7(3), 305-327.

Morozov, E. (2011). The net delusion: How not to liberate the world. London: Penguin UK.

Mukherjee, R., \& Banet-Weiser, S. (2012). Commodity activism: Cultural resistance in neoliberal times. New York, London: NYU Press.

Ott, B. L., \& Herman, B. D. (2003). Mixed messages: Resistance and reappropriation in rave culture. Western Journal of Communication (includes Communication Reports), 67(3), 249-270.

Ponte, S., \& Richey, L. A. (2014). Buying into development? Brand Aid forms of cause-related marketing. Third World Quarterly, 35(1), 65-87.

Radovic, K. (2012). H\&M dedicates an entire collection to WaterAid. Brandinmag. Retrieved from https:// www.brandingmag.com/2012/06/04/hm-dedicatesan-entire-collection-to-wateraid

Rettberg, J. W. (2014). Seeing ourselves through technology: How we use selfies, blogs and wearable devices to see and shape ourselves. New York: Springer.

Schroeder, J. E. (2002). Critical visual analysis. In R. Belk (Ed.), Qualitative research methods in marketing (pp. 303-321). Cheltenham: Edward Elgar Publishing.

Scott, J. C. (1985). Weapons of the weak: Everyday forms of peasant resistance. New Haven: Yale University Press.

Seppänen, J. (2001). Young people, researchers and Benetton: Contest interpretations of a Benetton advertisement picture. Nordicom Review, 22(1), 85-96.

Shirky, C. (2011). The political power of social media: Technology, the public sphere, and political change. Foreign Affairs, 90(1), 28-41.

Shugart, H., Waggoner, C. E., \& Hallstein, D. L. O. B. (2001). Mediating third-wave feminism: Appropriation as postmodern media practice. Critical Studies in Media Communication, 18(2), 194-210.

Simon, B. (2011). Not going to Starbucks: Boycotts and the out-scouring of politics in the branded world. Journal of Consumer Culture, 11(2), 145-167.

Skretting, K. (2004). Gode reklamefilmer? Etiske og estetiske perspektiver på Reklamefilmkvalitet [Good commercials? Ethical and aesthetical perspectives on commercial quality]. Kristiansand: IJ Forlaget.

Sturken, M., \& Cartwright, L. (2001). Practices of looking: An introduction to visual culture. New York: Oxford University Press.

Towner, T. L. (2017). Lessons from the social media revolution? A look back at social media's role in political campaigns and elections. In K. S. Burns (Ed.), Social media: A reference handbook (pp. 167-172). Santa Barbara, Denver: ABC-CLIO.

Tufekci, Z. (2013). "Not this one": Social movements, the attention economy, and microcelebrity networked activism. American Behavioral Scientist, 57(7), 848-870.

Valenzuela, S., Arriagada, A., \& Scherman, A. (2014). Facebook, Twitter, and youth engagement: A quasi-experimental study of social media use and protest behavior using propensity score matching. International Journal of Communication, 8(2014), 2046-2070.

Valenzuela, S., Correa, T., \& Gil de Zúñiga, H. (2018). Ties, likes, and tweets: Using strong and weak ties to explain differences in protest participation across Facebook and Twitter use. Political Communication, 35(1), 117-134.

Varman, R., \& Belk, R. (2009). Nationalism and ideology in an anticonsumption movement. Journal of Consumer Research, 36(4), 686-700.

Vézina, R., \& Paul, O. (1997). Provocation in advertising: A conceptualization and an empirical assessment. International Journal of Research in Marketing, 14(2), 177-192.

\section{About the Author}

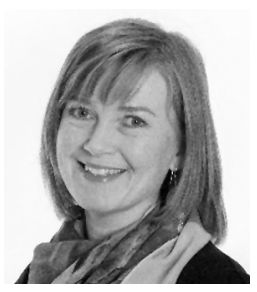

Trine Kvidal-Røvik (PhD) is Associate Professor at the Department of Tourism and Northern Studies, and the leader of the research group Narrating the Postcolonial North at UiT The Arctic University of Norway, Alta, Norway. Kvidal-Røvik's research interests include "media, representations, and power" and "media, place, and identity". She has published in anthologies on place and regional development and in journals such as Environmental Communication, Journal of Rural and Community Development, and Nordicom Review. 